\title{
Nitric Oxide/Peroxynitrite Redox Imbalance in Endothelial Cells Measured with Amperometric Nanosensors
}

\author{
Andrzej Burewicz, Hazem Dawoud, Lu-Lin Jiang, Tadeusz Malinski* \\ Department of Chemistry and Biochemistry, Ohio University, Athens, Ohio, USA \\ Email: ${ }^{*}$ malinski@ohio.edu
}

Received July 5, 2013; revised August 6, 2013; accepted September 1, 2013

Copyright (C) 2013 Andrzej Burewicz et al. This is an open access article distributed under the Creative Commons Attribution License, which permits unrestricted use, distribution, and reproduction in any medium, provided the original work is properly cited.

\begin{abstract}
The cytoprotective messenger nitric oxide (NO) and cytotoxic peroxynitrite $\left(\mathrm{ONOO}^{-}\right)$are the main components of oxidative stress and can be generated by endothelial cells. A tandem of electrochemical nanosensors (diameter $200-300$ $\mathrm{nm}$ ) were used to measure, in situ, the balance between $\mathrm{NO}$ and $\mathrm{ONOO}^{-}$produced by human umbilical vein endothelial cells (HUVEC's). The amperometric nanosensors were placed $5 \pm 2 \mu \mathrm{m}$ from the surface of the endothelial cells and the concentration of $\mathrm{NO}$ and $\mathrm{ONOO}^{-}$was measured at $630 \mathrm{mV}$ and $-300 \mathrm{mV}$ (vs $\mathrm{Ag} / \mathrm{AgCl}$ ) respectively. Normal, functional, endothelial cells produced maximal $450 \pm 25 \mathrm{nmol} \cdot \mathrm{L}^{-1}$ of $\mathrm{NO}$ and $180 \pm 15 \mathrm{nmol} \cdot \mathrm{L}^{-1}$ of $\mathrm{ONOO}^{-}$in about $3 \mathrm{~s}$, after stimulation with calcium ionophore. The in situ measurements of $\mathrm{NO}$ and $\mathrm{ONOO}^{-}$were validated using nitric oxide synthase inhibitor L-NMMA, $\mathrm{ONOO}^{-}$scavenger $\mathrm{Mn}(\mathrm{III})$ porphyrin, and superoxide dismutase (PEG-SOD). The ratio of $\mathrm{NO}$ concentration to $\mathrm{ONOO}^{-}$concentration $\left([\mathrm{NO}] /\left[\mathrm{ONOO}^{-}\right]\right)$was introduced for quantification of both, the redox balance and the level of the nitroxidative stress in the endothelium. [NO]/[ONOO $\left.{ }^{-}\right]$was $2.7 \pm 0.1$ in a functional endothelium. The model of the dysfunctional endothelium was made by the treatment of HUVEC's with angiotensin II for $20 \mathrm{~min}$. Dysfunctional HUVEC's produced only $115 \pm 15 \mathrm{nmol} \cdot \mathrm{L}^{-1}$ of $\mathrm{NO}$, but generated a significantly higher concentration of $\mathrm{ONOO}^{-}$of $490 \pm 30 \mathrm{nmol} \cdot \mathrm{L}^{-1}$. The $[\mathrm{NO}] /\left[\mathrm{ONOO}^{-}\right]$ratio decreased to $0.23 \pm 0.14$ in the dysfunctional endothelium. Electrochemical nanosensors can be effectively used for in situ monitoring of changing levels of nitroxidative/ oxidative stress, and may be useful in early medical diagnosis of the cardiovascular system.
\end{abstract}

Keywords: Nanosensors; Nitric Oxide; Peroxynitrite; Endothelium; Oxidative Stress

\section{Introduction}

Nitric oxide is a free radical with a half-life of less than five seconds, which has been found as a signaling molecule in both, the cardiovascular system and neurological system $[1,2]$. NO is involved in the relaxation of the arterial wall [3], acts as a mediator of immune system [4], and is a crucial neurotransmitter in the peripheral and central nervous systems [5]. NO can be produced by five electrons oxidation process of L-arginine by nitric oxide synthase (NOS). There are two constitutive nitric oxide synthase (cNOS): endothelial nitric oxide synthase (eNOS), and neuronal nitric oxide synthase (nNOS). These two enzymes are dimers. NO production from eNOS is stimulated by $\mathrm{Ca}^{2+}$-calmodulin dependent pathway. The time of NO production is about $5-20 \mathrm{~s}$ and $1-5 \mathrm{~s}$ by eNOS and nNOS, respectively [6]. Inducible nitric oxide synthase (iNOS) is a $\mathrm{Ca}^{2+}$-calmodulin independent enzyme and can produce NO for an extended period of time

\footnotetext{
"Corresponding author.
}

(up to hours) [7]. Intra-cellular $\mathrm{Ca}^{2+}$ flux into an endothelial cell triggers NO production by eNOS. NO is a small lipophilic molecule that can diffuse readily through cellular membranes and plasma to activate the soluble guanylate cyclase (sGC)/guanosine 3,5-cyclic monophosphate (cGMP) pathway in smooth muscle cells, platelets, and leukocytes [8-10]. Therefore, NO plays a vital role in maintaining vascular smooth muscle relaxation, inhibits the adhesion of platelets-leukocytes to endothelial cells and prevents platelet aggregation, also regulates blood flow and blood pressure $[3,11]$. NO is also a main scavenger of superoxide ion $\left(\mathrm{O}_{2}^{-}\right)$in biological milieu. Under pathological conditions, at high oxidative stress, most of the NO produced by endothelium or neurons is consumed in the reaction with $\mathrm{O}_{2}^{-}$to form peroxynitrite $\left(\mathrm{ONOO}^{-}\right)[12,13]$. $\mathrm{ONOO}^{-}$is much more powerful oxidant than $\mathrm{NO}$ or $\mathrm{O}_{2}^{-}$. High levels of $\mathrm{ONOO}^{-}$can cause DNA strands break, lipid peroxidation, trigger cell apoptosis via the activation of caspase cascade, and deactivate several enzymes [14]. The production of $\mathrm{ONOO}^{-}$not 
only increases the level of redox toxicity but also diminishes the concentration of bioavailable $\mathrm{NO}$, resulting in endothelial and/or neuronal dysfunction $[15,16]$. A dysfunctional endothelium has been found in patients with serious cardiovascular conditions, such as: hypertension, diabetes, atherosclerosis, coronary artery diseases, and chronic heart failure [17-19]. In addition, the dysfunction of the endothelium and neurons has also been implicated in several neurodegenerative diseases, such as, Alzheimer's disease [20], Lou Gehrig's disease (amyotrophic lateral sclerosis, ALS) [21], Parkinson's disease and epilepsy [2,22]. We hypothesized that the real-time measurements of balance/imbalance between the vital signaling molecule $\mathrm{NO}$ and the cytotoxic $\mathrm{ONOO}^{-}$may be useful as diagnostic tool to detect early dysfunction of cardiovascular or neurological system. Both $\mathrm{NO}$ and $\mathrm{ONOO}^{-}$are short living species with a half-life of $3 \mathrm{~s}$ and 1 s respectively [13]. Both $\mathrm{NO}$ and $\mathrm{ONOO}^{-}$molecules can react or form adducts with many other biological molecules. Therefore, the average distance of diffusion of these molecules is less than $100 \mu \mathrm{m}[23,24]$. Nanosensors were applied for in situ measurement of $\mathrm{NO}$ and $\mathrm{ONOO}^{-}$concentration produced by a single endothelial cell. These electrochemical nanosensors meet all fundamental requirements for this kind measurement: small enough in size (about $200-300 \mu \mathrm{m}$ ) to be placed near the membrane of an endothelial cell. The response time of the sensors is less than $50 \mu \mathrm{s}$ and the detection limit is about $10^{-9} \mathrm{~mol} \cdot \mathrm{L}^{-1}$.

\section{Materials and Methods}

\subsection{Materials}

Superoxide dismutase-polyethylene glycol (PEG-SOD); 3-Benzyl-7-(2-benzoxazolyl)thio-1,2,3-triazolo(4,5-6k) pyrimidine (VAS2870); calcium ionophore (CaI, A23187), $\mathrm{N}^{\mathrm{G}}$-Methyl-L-arginine acetate salt (L-NMMA), Mn(III) tetrakis (4-benzoic acid) porphyrin chloride (Mn(III) porphyrin) were purchased from Sigma-Aldrich (St. Louis, $\mathrm{MO})$.

\subsection{Subjects and Cell Cultures}

Human umbilical vein endothelial cells (HUVECs) were purchased as proliferating cells from Lonza (Walkersville, MD). Cells were cultured in the recommended MCDB-131 (Vec Technologies) complete medium and maintained at $37^{\circ} \mathrm{C}$ in a $5 \% \mathrm{CO}_{2}$ humidified incubator. Cells were supplied with a fresh medium every other day and propagated using an enzymatic dissociation (trypsin) procedure (maximum of 16 population doublings).

\subsection{Preparation of Nanosensors for NO and ONOO$^{-}$Detection}

$\mathrm{NO}$ and $\mathrm{ONOO}^{-}$were measured with nanosensors (di- ameter $200-300 \mathrm{~nm}$ ). The design of the nanosensors was based on previously developed chemically modified carbon fiber technology [25-27]. Briefly, the carbon fibers were sealed in glass capillaries with a non-conductive epoxy and electrically connected to copper wires with conductive sliver epoxy. A fiber (original diameter $7 \mathrm{~nm}$ ) was covered with a film of bee wax and rosin. The diameter of carbon fiber tip was reduced to about $300 \mathrm{~nm}$ by gradual burning of the fiber using a propane microburner. The exposed suface of the conical shape of the tip was covered with conductive polymeric porphyrin: polymeric nickel (II) tetrakis (3-methoxy-4-hydroxyphenyl) porphyrin (Frontier Scientific) for the NO sensor, and Mn (III)-[2, 2] paracyclophenyl-porphyrin (Frontier Scientific) for the $\mathrm{ONOO}^{-}$sensor, respectively. The polymeric porphyrinic film was covered with thin layer of Nafion for the NO sensor and with poly (4-vinylpyridine) for the $\mathrm{ONOO}^{-}$sensor.

\subsection{Amperometric Measurement of NO and $\mathrm{ONOO}^{-}$}

A three-electrode system has been utilized for amperometric measurement of $\mathrm{NO}$ and $\mathrm{ONOO}^{-}$. In this system, $\mathrm{NO}$ and $\mathrm{ONOO}^{-}$nanosensors served as working electrode; a silver/silver chloride $(\mathrm{Ag} / \mathrm{AgCl})$ as reference electrode, and a platinum wire (diameter $0.1 \mathrm{~mm}$ ) as a counter electrode. Amperometric measurement was performed by using a computer-controlled Gamry VFP600 multichannel potentiostat, which has been used to measure $\mathrm{NO}$ and $\mathrm{ONOO}^{-}$concentrations change from their basal levels with time. The detection limit is $1 \mathrm{nmol} \mathrm{L}^{-1}$ and the resolution time $<50 \mathrm{~ms}$. Linear calibration curves were constructed for each sensor in the range of 20 $\mathrm{nmol} \cdot \mathrm{L}^{-1}$ to $1 \mu \mathrm{mol} \cdot \mathrm{L}^{-1}$ of $\mathrm{NO}$ and $\mathrm{ONOO}^{-}$standard solution. A standard addition method was also used to calibrate the sensors after the measurement of $\mathrm{NO}$ and $\mathrm{ONOO}^{-}$in endothelial cells. Endothelial cells were placed in $2 \mathrm{~cm}$ wells to achieve confluence. A single sensor or tandem of $\mathrm{NO}$ and $\mathrm{ONOO}^{-}$sensors were placed in the well with a help of computerized remote controlled micromanipulator (Sensapex, Findland) with $x, y$, and $z$ space resolution of $1 \mu \mathrm{m}$. Sensors were lowered to a membrane level of the endothelial cell, sending a small piezoelectric signal of 6 to $8 \mathrm{pA}$, lasting 1 to $3 \mathrm{~ms}$, until the surface of the cell membranes was reached. This procedure helped to establish a zero distance from cell membrane on $z$ axis. From this point, the nanosensors were lifted about $5 \mu \mathrm{m}$ from the cell membrane and shifted horizontally along $x$ and $y$ axises about $30-50 \mu \mathrm{m}$. The sensors were positioned above a single endothelial cell. The measurements were done in a $0.1 \mathrm{~mol} \cdot \mathrm{L}^{-1}$ phosphate buffer (at $\mathrm{pH}$ 7.4) in the absence or presence of superoxide dismutase (PEG-SOD), $400 \mathrm{U} \cdot \mathrm{ml}^{-1}$; Mn(III) tetrakis (4-benzoic acid) porphyrin chlo- ride (Mn(III) porphyrin) 
$10 \mu \mathrm{mol} \cdot \mathrm{L}^{-1}$, a scavenger for $\mathrm{ONOO}^{-}$; VAS2870 1 $\mu \mathrm{mol} \cdot \mathrm{L}^{-1}$, a nicotinamide adenine dinucleotide phosphate (NADPH) oxidase selective inhibitor; or $\mathrm{N}^{\mathrm{G}}$-Methyl-Larginine acetate salt (L-NMMA) $0.4 \mathrm{mmol} \cdot \mathrm{L}^{-1}$, an inhibitor of constitutive $\mathrm{NOS}$. $\mathrm{NO} / \mathrm{ONOO}^{-}$release was stimulated by calcium ionophore (CaI, A23187), at a concentration of $1 \mu \mathrm{mol} \cdot \mathrm{L}^{-1}$, injected via a nanoinjector positioned with a computer-controlled micromanipulator.

\subsection{Calculations and Statistical Analysis}

All data are presented as mean \pm standard deviation (SD) of the mean of $n=3-5$. Statistical analysis of the mean difference between multiple groups was performed using one-way analysis of variance (ANOVA) with StudentNewman-Keuls multiple comparisons post hoc analysis; and between two groups, using two-tailed Student's t-test. The alpha level for all the tests was 0.05 . A $\mathrm{P}$ value $<$ 0.05 was considered to be statistically significant. All statistical analyses were performed using Origin (v 6.1 for Windows; OriginLab, Northampton, MA).

\section{Results and Discussion}

Nanosensors were placed near the surface of HUVEC cells. An accurate positioning of the nanosensors in the relation to the cell membrane surface is crucially important in order to obtain reproducible results. The nanosensors cannot be placed directly on the surface of endothelial cells because they will stimulate $\mathrm{NO}$ and $\mathrm{ONOO}^{-}$ release through activation of mechanical channels and calcium flux to cytoplasm.

Figure 1 depicts a change of NO concentration as a function of the distance from endothelial cell membrane. The NO concentration decreases exponentially with a distance from a surface of the membrane. The process of NO diffusion from a membrane of the cell depends directly on the gradient of concentration between the membrane surface and buffer solution or cytoplasm. In the phosphate buffer, NO concentration is decreased by $50 \%$ at the distance of about $30 \mu \mathrm{m}$ from the membrane

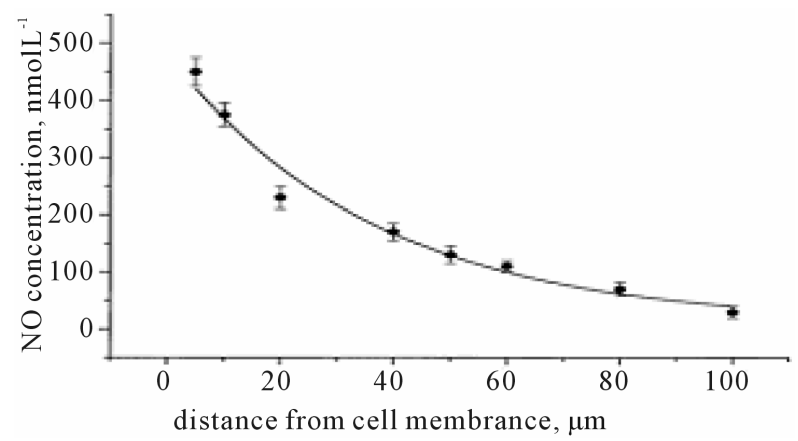

Figure 1. A decrease of NO concentration with an increasing distance from the cell membrane, measured with nanosensors. surface. The slope of the concentration-distance curve depends also on a redox environment of the medium. In the phosphate buffer NO will primarily react with oxygen to form nitrite.

Many potential redox reactions, as well as formation of adducts of NO to other biological molecules may deplete the concentration of bioavailable NO much more rapidly.

\subsection{Release of $\mathrm{NO}$ and $\mathrm{ONOO}^{-}$from Functional HUVEC's}

Figure 2 depicts typical amperograms recorded with NO and $\mathrm{ONOO}^{-}$nanosensors placed $5 \pm 2 \mu \mathrm{m}$ from the membrane surface of HUVEC's. $\mathrm{NO} / \mathrm{ONOO}^{-}$release was stimulated by receptor independent eNOS agonistcalcium ionophore $(\mathrm{CaI})$. The potential of the NO sensor was maintained at a constant level of $630 \mathrm{mV}$ vs $\mathrm{Ag} /$ $\mathrm{AgCl}$ and $-300 \mathrm{mV}$ vs $\mathrm{Ag} / \mathrm{AgCl}$ for $\mathrm{ONOO}^{-}$sensor.

A rapid increase in both $\mathrm{NO}$ and $\mathrm{ONOO}^{-}$concentration was observed about $200 \mathrm{~ms}$ after the stimulation with CaI. A maximal NO concentration of $425 \pm 30$ $\mathrm{nmol} \cdot \mathrm{L}^{-1}$ and maximal $\mathrm{ONOO}^{-}$concentration of $160 \pm$ $20 \mathrm{nmol} \cdot \mathrm{L}^{-1}$ was reached after about $3 \mathrm{~s}$. A rapid decline

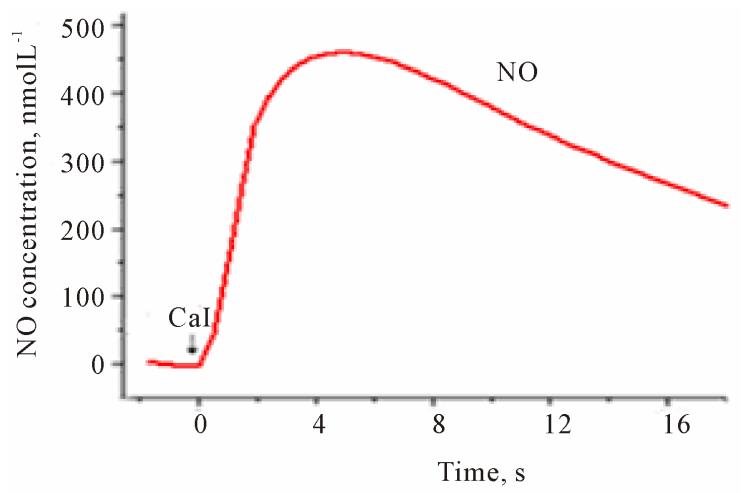

(a)

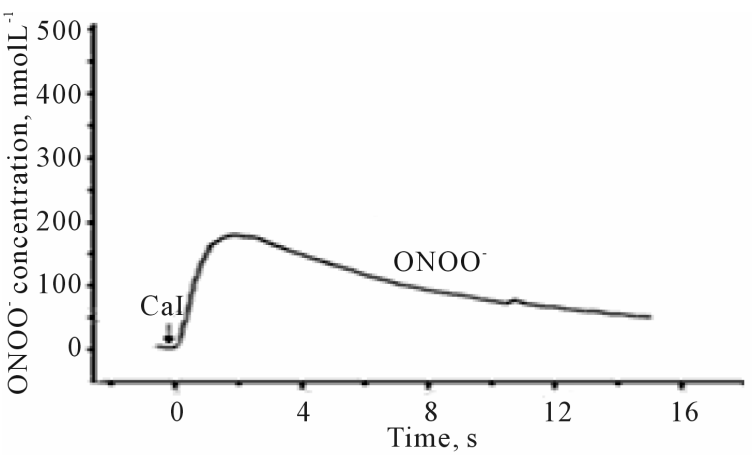

(b)

Figure 2. Amperograms showing NO release (a) and $\mathrm{ONOO}^{-}$ release (b) from HUVEC's cells. Current/concentration was measured at potential $630 \mathrm{mV}$ and $-300 \mathrm{mV}$ vs $\mathrm{Ag} / \mathrm{AgCl}$ for NO and $\mathrm{ONOO}^{-}$nanosensor respectively, after stimulation with CaI (A23187), concentration: $1.0 \mu \mathrm{mol} \cdot \mathrm{L}^{-1}$. 
in the concentration of both $\mathrm{NO}$ and $\mathrm{ONOO}^{-}$to their basal level was noticed after $4-6$ s.

\subsection{Validation of the Method}

The method was validated for selectivity by adjusting a pathway of $\mathrm{NO}$ and $\mathrm{ONOO}^{-}$production. The constitutive nitric oxide synthase can be inhibited by L-arginine analog, L-NMMA, $\mathrm{ONOO}^{-}$can be scavenged by $\mathrm{Mn}(\mathrm{III})$ porphyrin. $\mathrm{O}_{2}^{-}$generated by eNOS can be inhibited by L-NMMA and $\mathrm{O}_{2}^{-}$generated by NADPH oxidase can be inhibited by specific inhibitor, VAS2870. Also, SOD can convert $\mathrm{O}_{2}^{-}$to $\mathrm{H}_{2} \mathrm{O}_{2}$.

Figure 3 shows examples of $\mathrm{NO}$ and $\mathrm{ONOO}^{-}$amperograms recorded in the presence of membrane permeable PEG-SOD or in the presence of an inhibitor of eNOS, L-NMMA. In the presence of PEG-SOD, a significant increase (about 20\%) in NO and decrease in $\mathrm{ONOO}^{-}$(about 70\%) was observed. As expected, an inhibition of eNOS by L-NMMA significantly decreased the production of both $\mathrm{NO}$ and $\mathrm{ONOO}^{-}$.

Maximal $\mathrm{NO}$ and $\mathrm{ONOO}^{-}$concentration are listed in Figure 4(a). PEG-SOD increased NO concentration from $420 \pm 30$ to $490 \pm 25 \mathrm{nmol} \cdot \mathrm{L}^{-1}$. PEG-SOD is very efficient agent in converting $\mathrm{O}_{2}^{-}$to $\mathrm{HO}_{2}^{-}$. There are two major sources of $\mathrm{O}_{2}^{-}$in the endothelium: eNOS and NADPH oxidase. In functional endothelium, the production of NO by eNOS is always accompanied by generation of minute concentration of $\mathrm{O}_{2}^{-} \cdot \mathrm{O}_{2}^{-}$plays a regulatory physiological role in the prevention of an overproduction of NO by endothelium. A product of NO reaction with $\mathrm{O}_{2}^{-}$is toxic peroxynitrite, $\mathrm{ONOO}^{-}$. In functional endothelium, at low concentration, $\mathrm{ONOO}^{-}$cannot diffuse a significant distance and is converted to nontoxic $\mathrm{NO}_{3}^{-}$.

In the presence of L-NMMA, the maximal concentration of $\mathrm{NO}$ and $\mathrm{ONOO}^{-}$was reduced to $85 \pm 10 \mathrm{nmol} \cdot \mathrm{L}^{-1}$ and $30 \pm 5 \mathrm{nmol} \cdot \mathrm{L}^{-1}$ respecitviely. $\mathrm{Mn}(\mathrm{III})$ porphyrin decreased only a concentration of $\mathrm{ONOO}^{-}$to $45 \pm 7$

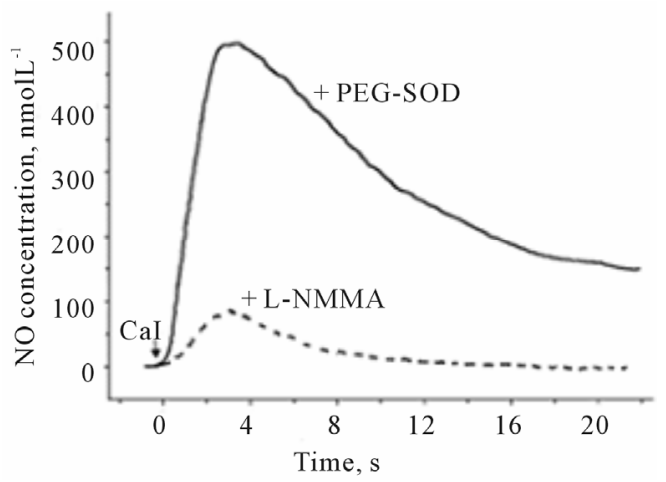

(a) nmol $\cdot \mathrm{L}^{-1}$, while VAS2870 decreased $\mathrm{ONOO}^{-}$to $105 \pm$ $15 \mathrm{nmol} \cdot \mathrm{L}^{-1}$ and increased NO to high level of $505 \pm 25$ $\mathrm{nmol} \cdot \mathrm{L}^{-1}$.

\section{3. $[\mathrm{NO}] /\left[\mathrm{ONOO}^{-}\right]$Balance}

We hypothesized that a balance between NO concentration $([\mathrm{NO}])$ and $\mathrm{ONOO}^{-}$concentration $\left(\left[\mathrm{ONOO}^{-}\right]\right)$may be a simple indicator to characterize the function or dysfunction of endothelial cells. Figure 4(b) depicts [NO]/ $\left[\mathrm{ONOO}^{-}\right]$ratio calculated based on direct measurement of $\mathrm{NO}$ and $\mathrm{ONOO}^{-}$with nanosensors.

The simultaneous in close proximity at near real time measurement of both $\mathrm{NO}$ and $\mathrm{ONOO}^{-}$provides a unique analytical capability for quantitation of cytoprotective $\mathrm{NO}$ and cytotoxic $\mathrm{ONOO}^{-}$-the main component of oxidative stress. In the normal, functional, endothelium, a ratio of $[\mathrm{NO}] /\left[\mathrm{ONOO}^{-}\right]$stimulated by $\mathrm{CaI}$ is $2.7 \pm 0.1$ and increases in the presence of PEG-SOD to $4.1 \pm 0.1$. An inhibition of eNOS with L-NMMA decreased level of both $\mathrm{NO}$ and $\mathrm{ONOO}^{-}$and did not change significantly their ratio $(2.8 \pm 0.2$ in the presence of L-NMMA). The most significant change of $[\mathrm{NO}] /\left[\mathrm{ONOO}^{-}\right](10.0 \pm 0.2)$ was observed in the presence of $\mathrm{Mn}$ (III) porphyrin. $\mathrm{Mn}(\mathrm{III})$ porphyrin efficiently scavenged $\mathrm{ONOO}^{-}$and shows a minimal effect on NO. Therefore, Mn(III) porphyrin is the most effective in improving [NO]/[ONOO $\left.{ }^{-}\right]$ redox balance in endothelium by removing most of $\mathrm{ONOO}^{-}$.

Based on our previous studies, we established that at a balance of $[\mathrm{NO}] /\left[\mathrm{ONOO}^{-}\right]$higher than 1.0 , a damage imposed on endothelium by oxidative stress is minimal. However, at ratio of $[\mathrm{NO}] /\left[\mathrm{ONOO}^{-}\right]$lower than 1.0 , the nitroxidative stress imposed by $\mathrm{ONOO}^{-}$produced by endothelium becomes highly significant [19]. Therefore, some pharmacological interventions, such as treatment with statins, may have significant therapeutic effect on increasing $[\mathrm{NO}] /\left[\mathrm{ONOO}^{-}\right]$balance and restoring a function of vascular endothelium.

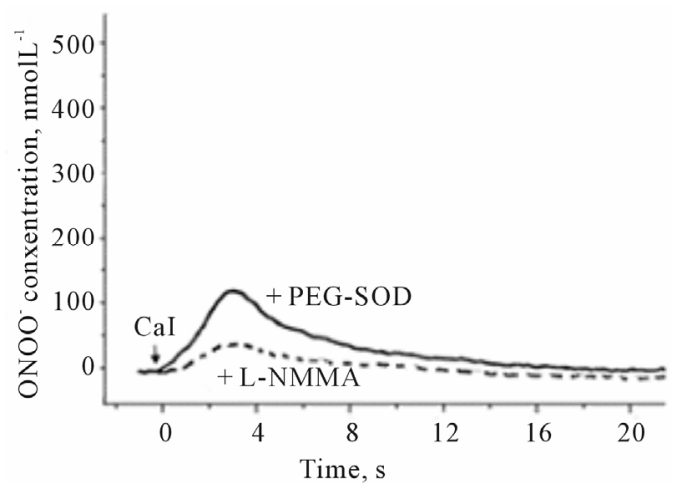

(b)

Figure 3. Amperograms showing NO (a) and $\mathrm{ONOO}^{-}$(b) release from HUVEC's after stimulation with CaI (A23187, 1.0 $\mu \mathrm{mol} \cdot \mathrm{L}^{-1}$ ). The measurements were performed in the presence of PEG-SOD (solid line) or L-NMMA (dashed line). 


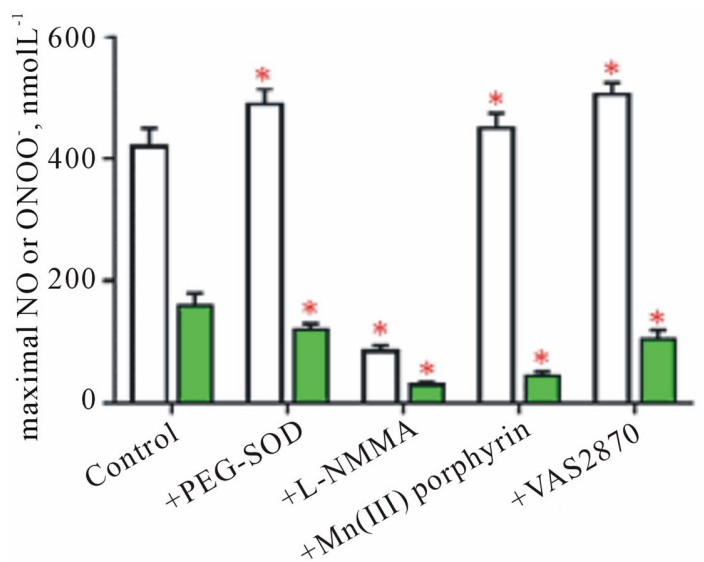

(a)

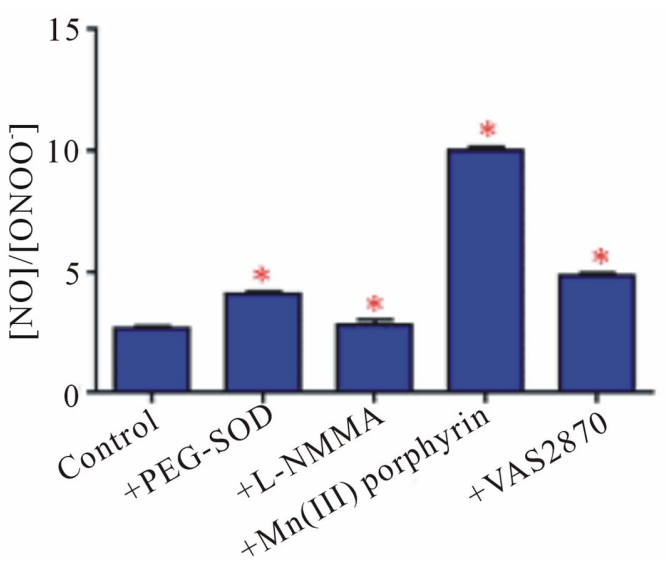

(b)

Figure 4. Maximal NO (open bars) and $\mathrm{ONOO}^{-}$(solid bars) concentrations released from HUVECs in an absence or in the presence of PEG-SOD, L-NMMA, VAS 2870, Mn(III) porphyrin (a). A ratio of maximal NO concentration to maximal $\mathrm{ONOO}^{-}$concentration measured from HUVEC cells in the absence or presence of PEG-SOD, L-NMMA, Mn(III) porphyrin, VAS 2870 (b). ( $(\mathrm{p}<0.05$ vs control, $n=3$ ).

\subsection{Measurements of $\mathrm{NO}$ and $\mathrm{ONOO}^{-}$ Concentration in Dysfunctional Endothelium}

A prolong treatment of HUVEC's with angiotensin II leads to a dysfunction of endothelium and the dysfunction of eNOS. Angiotensin II stimulates NO production by activating angiotensin receptors. This process of angiotensin II stimulating NO production is one of the fundamental mechanisms to regulate blood flow and blood pressure. However, a long time exposure to elevated level of angiotensin II can lead to an increase in blood pressure and other cardiovascular diseases.

In the analytical model presented here, HUVEC's were treated with angiotensin II to mimic the condition of dysfunctional endothelium in the cardiovascular system. After $20 \mathrm{~min}$ treatment with angiotensin II (1 $\mu \mathrm{mol} \cdot \mathrm{L}^{-1}$ ), cells were stimulated with $\mathrm{CaI}$ and the release of $\mathrm{NO}$ and $\mathrm{ONOO}^{-}$was monitored with nanosensors (Figures 5(a) and (b)). Angiotensin II induced dysfunction of endothelium has shown a significant decrease in bioavailable $\mathrm{NO}$ with concomitant increase in $\mathrm{ONOO}^{-}$. A maximal NO concentration generated by HUVEC's decreased to $115 \pm 15 \mathrm{nmol} \cdot \mathrm{L}^{-1}$, about $70 \%$ decrease as compared to normal functional endothelial cells. A massive increase in $\mathrm{ONOO}^{-}, 490 \pm 30 \mathrm{nmol} \cdot \mathrm{L}^{-1}$ accompanied the decrease in NO concentration. A balance between $[\mathrm{NO}] /\left[\mathrm{ONOO}^{-}\right]$was shifted from $2.7 \pm 0.1$ in functional endothelium to $0.23 \pm 0.14$ in the dysfunctional endothelium (Figures 5(c) and (d)). This reflects changes in cellular environment to highly oxidative one with $\mathrm{ONOO}^{-}$as the dominating nitroxidative power. In the model of dysfunctional endothelium presented here about $80 \%$ of $\mathrm{O}_{2}^{-}$is produced by disarranged eNOS dimer (Figure 6(a)) which produces $\mathrm{NO}$ and $\mathrm{O}_{2}^{-}$con- comitantly. Therefore eNOS is very efficient generator of $\mathrm{ONOO}^{-}$. $\mathrm{NO}$ and $\mathrm{ONOO}^{-}$are released in close proximity, and the reaction between these two molecules is fast, and diffusion controlled with rate higher than $5.0 \times 10^{9}$. However, in the endothelium, $\mathrm{O}_{2}^{-}$can be also generated by other sources including NADPH oxidase. In the model of CaI stimulation $\mathrm{NO} / \mathrm{ONOO}^{-}$, a contribution of $\mathrm{NADPH}$ oxidase toward production of $\mathrm{ONOO}^{-}$is much smaller than the contribution of eNOS (about $30 \%$ ).

A net final effect of these processes is a switch of the redox enviorment from controlled by cyroprotective NO to controlled by the cytotoxic $\mathrm{ONOO}^{-}$. A high oxidative/ nitroxidative stress increased by $\mathrm{ONOO}^{-}$can trigger a cascade of events leading to DNA strands break, lipid peroxidation, trigger cell apoptosis via the activation of caspase cascade, deactivate several enzymes and may be a significant factor in cardiovascular diseases including hypertension, diabetes, and atherosclerosis. It has been suggested that the oxidative power of $\mathrm{ONOO}^{-}$rely on the highly aggressive species like $\mathrm{OH}, \mathrm{NO}_{2}$ generated during homolytic or heterolytic cleavage of this molecule (Figure 6(b)).

\section{Conclusion}

The work presented here has clearly demonstrated that amperometric nanosensors can be successfully applied for in situ measurement of $\mathrm{NO}$ and $\mathrm{ONOO}^{-}$, and to monitor the changes in nitroxidative stress in endothelial cells. A balance of $[\mathrm{NO}] /\left[\mathrm{ONOO}^{-}\right]$can be dramatically changed in dysfunctional endothelium under pathological condition. This change can be related to cardiovascular diseases like hypertension, atherosclerosis, diabetes, and heart failure. Therefore, $\mathrm{NO}, \mathrm{ONOO}^{-}$markers and nanomedical approach can be effectively used for early 


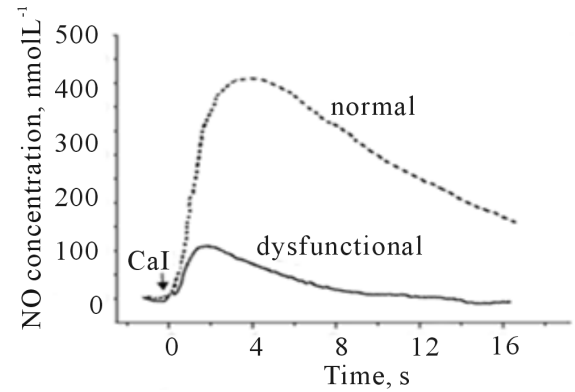

(a)

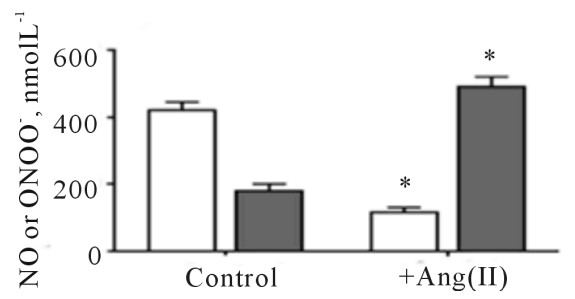

(c)

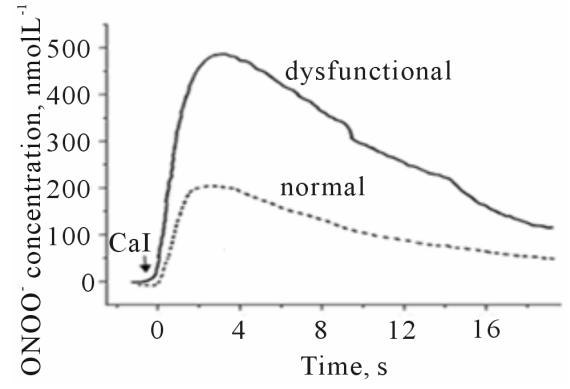

(b)

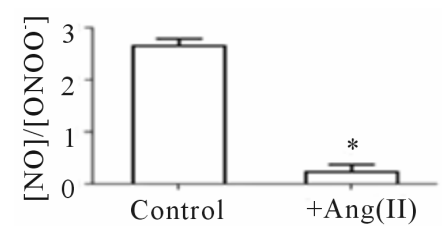

(d)

Figure 5. Amperograms showing NO (a) and $\mathrm{ONOO}^{-}$(b) release from normal (dashed line) and dysfunctional (solid line) HUVECs. A maximal NO and $\mathrm{ONOO}^{-}$concentrations measured for nor-mal (open bar) and dysfunctional (solid bar) endothelium (c). The ratio of $\mathrm{NO}^{\text {to }} \mathrm{ONOO}^{-}$maximal concentrations produced from normal and dysfunctional HUVECs (d). ( ${ }^{*} \mathrm{p}<$ 0.05 vs control, $n=5)$.

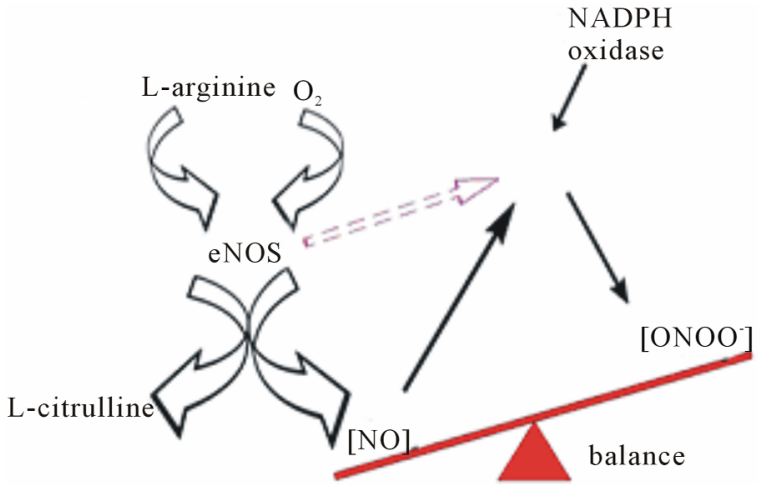

(a)

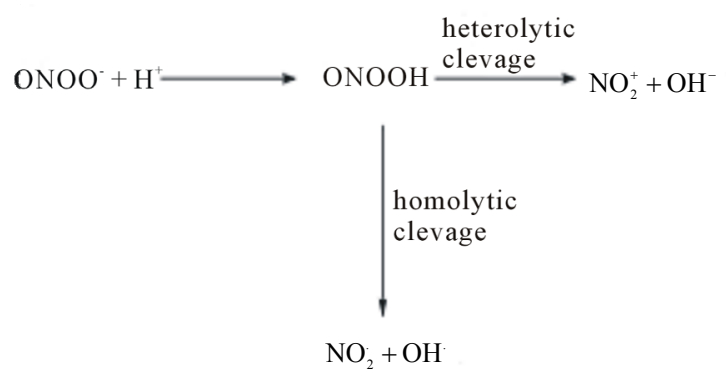

(b)

Figure 6. Reaction mechanism leading to imbalance between NO and $\mathrm{ONOO}^{-}$in the dysfunctional HUVECs (a). An homolytic and heterolytic cleavage of $\mathrm{ONOO}^{-}$to $\mathrm{OH} \bullet, \mathrm{NO}_{2} \bullet$ and $\mathrm{NO}_{2}^{-}$components of the oxidative/nitroxidative stress (b).

diagnosis of cardiovascular dysfunction.

\section{Acknowledgements}

A partial support for this work from RO1 CA086928 and Marvin White Endowment at Ohio University is acknowledged. Also, we thank Paula Hale and Collin Arocho for technical assistance.

\section{REFERENCES}

[1] T. Malinski and Z. Taha, "Nitric Oxide Release from a Single Cell Measured in Situ by a Porphyrinic-Based Microsensor," Nature, Vol. 358, No. 6388, 1992, pp. 676678. http://dx.doi.org/10.1038/358676a0
[2] L. J. Ignarro, "Endothelium-Derived Nitric Oxide: Actions and Properties," FASEB Journal, Vol. 3, No. 1, 1989, pp. 31-36.

[3] L. A. Blatter, Z. Taha, S. Mesaros, P. S. Shacklock, W. G. Wier and T. Malinski, "Simultaneous Measurements of $\mathrm{Ca}^{2+}$ and Nitric Oxide in Bradykinin-Stimulated Vascular Endothelial Cells," Circulation Research, Vol. 76, No. 5, 1995, pp. 922-924.

http://dx.doi.org/10.1161/01.RES.76.5.922

[4] J. B. Hibbs, Jr., Z. Vavrin and R. R. Taintor, "L-Arginine Is Required for Expression of the Activated Macrophage Effector Mechanism Causing Selective Metabolic Inhibition in Target Cells," Journal of Immunology, Vol. 138, No. 2, 1987, pp. 550-565.

[5] S. H. Snyder and D. S. Bredt, "Nitric Oxide as a Neuronal 
Messenger," Trends in Pharmacological Sciences, Vol. 12, No. 4, 1991, pp. 125-128. http://dx.doi.org/10.1016/0165-6147(91)90526-X

[6] T. Malinski, Z. Taha, S. Grunfeld, S. Patton, M. Kapturczak and P. Tomboulian, "Diffusion of Nitric Oxide in the Aorta Wall Monitored in Situ by Porphyrinic Microsensors," Biochemical and Biophysical Research Communications, Vol. 193, No. 3, 1993, pp. 1076-1082. http://dx.doi.org/10.1006/bbrc.1993.1735

[7] J. L. Balligand, D. Ungureanu-Longrois, W. W. Simmons, D. Pimental, T. A. Malinski, M. Kapturczak et al., "Cytokine-Inducible Nitric Oxide Synthase (iNOS) Expression in Cardiac Myocytes. Characterization and Regulation of iNOS Expression and Detection of iNOS Activity in Single Cardiac Myocytes in Vitro," Journal of Biological Chemistry, Vol. 269, No. 44, 1994, pp. 2758027588.

[8] W. P. Arnold, C. K. Mittal, S. Katsuki and F. Murad, "Nitric Oxide Activates Guanylate Cyclase and Increases Guanosine 3':5'-Cyclic Monophosphate Levels in Various Tissue Preparations," Proceedings of the National Academy of Sciences of the United States of America, Vol. 74, No. 8, 1977, pp. 3203-3207.

http://dx.doi.org/10.1073/pnas.74.8.3203

[9] L. J. Ignarro, "Nitric Oxide: A Unique Endogenous Signaling Molecule in Vascular Biology," Bioscience Reports, Vol. 19, No. 2, 1999, pp. 51-71. http://dx.doi.org/10.1023/A:1020150124721

[10] L. J. Ignarro, J. B. Adams, P. M. Horwitz and K. S. Wood, "Activation of Soluble Guanylate Cyclase by NO-Hemoproteins Involves NO-Heme Exchange. Comparison of Heme-Containing and Heme-Deficient Enzyme Forms," Journal of Biological Chemistry, Vol. 261, No. 11, 1986, pp. 4997-5002.

[11] S. Grunfeld, C. A. Hamilton, S. Mesaros, S. W. McClain, A. F. Dominiczak, D. F. Bohr et al., "Role of Superoxide in the Depressed Nitric Oxide Production by the Endothelium of Genetically Hypertensive Rats," Hypertension, Vol. 26, No. 6, 1995, pp. 854-857.

http://dx.doi.org/10.1161/01.HYP.26.6.854

[12] J. S. Beckman, T. W. Beckman, J. Chen, P. A. Marshall and B. A. Freeman, "Apparent Hydroxyl Radical Production by Peroxynitrite: Implications for Endothelial Injury from Nitric Oxide and Superoxide," Proceedings of the National Academy of Sciences of the United States of America, Vol. 87, No. 4, 1990, pp. 1620-1624. http://dx.doi.org/10.1073/pnas.87.4.1620

[13] J. S. Beckman and W. H. Koppenol, "Nitric Oxide, Superoxide, and Peroxynitrite: The Good, the Bad, and Ugly," American Journal of Physiology, Vol. 271, No. 5, 1996, pp. C1424-C1437.

[14] A. J. Kozak, F. Liu, P. Funovics, A. Jacoby, R. Kubant and T. Malinski, "Role of Peroxynitrite in the Process of Vascular Tone Regulation by Nitric Oxide and Prostanoids-A Nanotechnological Approach," Prostaglandins Leukot Essent Fatty Acids, Vol. 72, No. 2, 2005, pp. 105113. http://dx.doi.org/10.1016/j.plefa.2004.10.007

[15] T. Malinski, "Normal and Pathological Distribution of
Nitric Oxide in the Cardiovascular System," Polish Journal of Pharmacology, Vol. 50, No. 6, 1998, pp. 387-391.

[16] T. Malinski, "Nitric Oxide Signaling in the Cardiovascular System-Physiology and Pathology," Postepy Higieny i Medycyny Doświadczalnej, Vol. 53, No. 2, 1999, pp. 205207.

[17] L. Kalinowski and T. Malinski, "Endothelial NADH/ NADPH-Dependent Enzymatic Sources of Superoxide Production: Relationship to Endothelial Dysfunction," Acta Biochimica Polonica, Vol. 51, No. 2, 2004, pp. 459469.

[18] R. P. Mason, L. Kalinowski, R. F. Jacob, A. M. Jacoby and T. Malinski, "Nebivolol Reduces Nitroxidative Stress and Restores Nitric Oxide Bioavailability in Endothelium of Black Americans," Circulation, Vol. 112, No. 24, 2005, pp. 3795-3801.

http://dx.doi.org/10.1161/CIRCULATIONAHA.105.5562 $\underline{33}$

[19] R. P. Mason, R. Kubant, R. F. Jacob, M. F. Walter, B. Boychuk and T. Malinski, "Effect of Nebivolol on Endothelial Nitric Oxide and Peroxynitrite Release in Hypertensive Animals: Role of Antioxidant Activity," Journal of Cardiovascular Pharmacology, Vol. 48, No. 1, 2006, pp. 862-869.

http://dx.doi.org/10.1097/01.fjc.0000238593.67191.e2

[20] T. Malinski, "Nitric Oxide and Nitroxidative Stress in Alzheimer's Disease," Journal of Alzheimer's Disease, Vol. 11, No. 2, 2007, pp. 207-218.

[21] D. R. Rosen, T. Siddique, D. Patterson, D. A. Figlewicz, P. Sapp, A. Hentati, et al., "Mutations in Cu/Zn Superoxide Dismutase Gene Are Associated with Familial Amyotrophic Lateral Sclerosis," Nature, Vol. 362, No. 6415, 1993, pp. 59-62. http://dx.doi.org/10.1038/362059a0

[22] R. F. Furchgott, "Endothelium-Derived Relaxing Factor: Discovery, Early Studies, and Identification as Nitric Oxide," Bioscience Reports, Vol. 19, No. 4, 1999, pp. 235 251. http://dx.doi.org/10.1023/A:1020537506008

[23] D. I. Levy, N. J. Sucher and S. A. Lipton, "Redox Modulation of NMDA Receptor-Mediated Toxicity in Mammalian Central Neurons," Neuroscience Letters, Vol. 110, No. 3, 1990, pp. 291-296. http://dx.doi.org/10.1016/0304-3940(90)90862-4

[24] J. Wood and J. Garthwaite, "Models of the Diffusional Spread of Nitric Oxide: Implications for Neural Nitric Oxide Signalling and Its Pharmacological Properties," Neuropharmacology, Vol. 33, No. 11, 1994, pp. 1235-1244. http://dx.doi.org/10.1016/0028-3908(94)90022-1

[25] V. Brovkovych, S. Patton, S. Brovkovych, F. Kiechle, I. Huk and T. Malinski, "In Situ Measurement of Nitric Oxide, Superoxide and Peroxynitrite during Endotoxemia," Journal of Physiology and Pharmacology, Vol. 48, No. 4, 1997, pp. 633-644.

[26] J. Xue, X. Ying, J. Chen, Y. Xian and L. Jin, “Amperometric Ultramicrosensors for Peroxynitrite Detection and Its Application toward Single Myocardial Cells," Analytical Chemistry, Vol. 72, No. 21, 2000, pp. 5313-5321. http://dx.doi.org/10.1021/ac000701e 